\title{
An analysis of public-private partnership contractual incentives in Brazilian citizen service centers
}

\author{
André Schifnagel Avrichir ${ }^{1}$
}

1 Fundação Getulio Vargas / Escola de Administração de Empresas de São Paulo (FGV EAESP), São Paulo / SP — Brazil

This research uses a multiple case study approach to assess theoretical propositions from transaction costs economics, the theory of incentives, and the theory of incomplete contracts. The Poupatempo and the Unidades de Atendimento Integrado (UAI), which are two major Brazilian regional citizen service centers, were the cases selected based on an unusual opportunity: the parallel occurrence of two different arrangements of public-private partnership, applied to the same public service. Poupatempo has expanded its network of units since 2007 by building partnerships through outsourcing, whereas UAI has applied the Brazilian legal framework for public-private partnership to develop its services. This multiple case study is based on a contractual analysis that identifies the partnerships' formal incentives and on an examination of private agents' performance. Also, subsidiary semi-structured interviews allowed the observation of non-contractual variables.

Keywords: public policies; public-private partnership; outsourcing; citizen services delivery.

\section{Uma análise de incentivos contratuais em arranjos de parceria de atendimento ao cidadão}

Este artigo conduz um estudo de casos múltiplos para observar proposições teóricas da teoria dos custos de transação, teoria dos incentivos e teoria dos contratos incompletos. Os casos foram selecionados a partir de uma oportunidade não usual: a ocorrência simultânea de dois casos diferentes de arranjos público-privados aplicadas para um mesmo tipo de serviço público. O Poupatempo e o Unidades de Atendimento Integrado (UAI) são dois dos principais serviços estaduais brasileiros de atendimento presencial ao cidadão e recentemente implementaram diferentes modelos de parceria com parceiros privados. Para expandir a rede de postos, o Poupatempo passou a terceirizar suas unidades em 2007. O UAI, por sua vez, desenvolveu uma parceria público-privada no contexto legal brasileiro. Esse estudo de casos múltiplos foi desenvolvido com base em uma análise contratual que identificou a estrutura formal de incentivos das parcerias e na avaliação de desempenho dos parceiros privados. De maneira subsidiaria, foram realizadas entrevistas semiestruturadas que permitiram a análise de variáveis não contratuais.

Palavras-chave: políticas públicas; parceria público-privada; terceirização; serviços de atendimento ao cidadão.

\section{Un análisis de incentivos contractuales en arranjos de asociación de atención al ciudadano}

Este artículo conduce un estudio de casos múltiples para observar proposiciones teóricas de la teoría de los costos de transacción, teoría de los incentivos y teoría de los contratos incompletos. Los casos fueron seleccionados a partir de una oportunidad no usual: la ocurrencia simultánea de dos casos diferentes de arreglos público-privados aplicados para un mismo tipo de servicio público. El Poupatempo y las Unidades de Atención Integrada (UAI) son dos de los principales servicios estaduales brasileños de atención presencial al ciudadano y recientemente implementaron diferentes modelos de asociación con socios privados. Para expandir la red de puestos, el Poupatempo pasó a subcontratar sus unidades en 2007. El UAI, a su vez, desarrolló una asociación público-privada en el contexto legal brasileño. Este estudio de casos múltiples se desarrolló sobre la base de un análisis contractual que identificó la estructura formal de incentivos de las asociaciones y la evaluación del desempeño de los socios privados. De manera subsidiaria, se realizaron entrevistas semiestructuradas que permitieron el análisis de variables no contractuales. Palabras clave: políticas públicas; asociación público-privada; terceirização; servicios de atención al ciudadano. 


\section{INTRODUCTION}

Although the delegation of public activities to private agents is no rare topic in the Brazilian public debate (Périco and Aparecida, 2005), scholars have turned their focus to the subject's legal issues. As a consequence, potential benefits and results of public delegation have been left aside in recent scholars work (Ribeiro, 2011; Rosilho, 2011). Meanwhile, particularly since the 1990s, Brazil's need to develop practice and knowledge on this topic has increased as the state proliferated public-private partnership frameworks (Périco and Aparecida, 2005; Thamer and Lazzarini, 2015).

Facing this need, through local case analysis this research seeks to answer the following question: how do public-private partnership (PPP) and outsourcing contractually established incentive structures influence private partners' performance? By answering this question with a managerial approach based on incentives and performance we look forward to contribute to the local literature on public outsourcing and PPPs.

Minas Gerais state government's Unidades de Atendimento Integrado (UAI) has since 2011 expanded its network based on a public-private partnership. Meanwhile, São Paulo state government's Poupatempo (saving time), one of the most renowned citizen service center enterprises in Brazil, has since 2007 outsourced its centers to the private sector. This contractual arrangement has an objective and frame distinct from PPPs.

\section{BACKGROUND}

Global debate about best practices for citizen service deliver is sound and developed and today looks towards concepts as open government (Askim et al., 2011; Wiseman, 2014). Theoretical development has gone hand to hand with best local government experiences worldwide. In Brazil, however, although some scholars have kept pace with international issues, government practices have lacked behind, still focusing on citizen service centers based on the one stop-shop (OSS) model. Over the last thirty years, 23 of the 27 local state governments developed OSS networks, however, the practice of more modern models of service provision remain rare (Ferrer, 2012; Golçalves, 2003).

In OSS policies different governmental institutions offer their services in one single location, allowing citizens to gather the necessary information and to obtain the demanded services with a single journey. The model results in a sort of public services shopping center (Askim et al., 2011).

The two selected cases, therefore, comprehend citizen service centers developed by two of the richest state governments in Brazil, São Paulo and Minas Gerais. Both keep many similarities based on the same OSS model. This case selection, however, happened based on the particularity of these two public policies amongst other similar local cases: to offer its services relying on private companies under different contractual incentive arrangements. These governmental partnership practices are recent alternatives in the local context for this sort of public activity and are yet to be object of further research (Ferrer, 2012; Majeed, 2014). 


\subsection{DELEGATION OF PUBLIC ACTIVITIES TO PRIVATE AGENTS IN BRAZIL}

Until the 1990s the only method government could apply to delegate public activities to private agents was to contract it out. Regulated in the 1990s, outsourcing keeps the state responsible to build and operate an infrastructure allowing it only to hire private companies for subsidiary products and services. Thus, by outsourcing government is bounded to design and perform with in-house work or hire a private agent to project and execute the necessary task, thus, bearing the entire enterprise financial burden. The fiscal charge, however, is parceled throughout the contract. Therefore, through this organizational frame, government can at most transfer to the private actor some activities for an agreed fee.

Outsourcing does not involve any sort of public asset sale. By transferring to private companies only subsidiary activities, management and operation for a maximum period of 60 months, it preserves government's ultimate responsibility for the venture (Rosilho, 2011). Further, contracting out allows the private agent little room for autonomy leaving it obligated only to deliver the acquired product on time. Remuneration usually occurs according to a fixed periodic amount with little variation depending on performance (Rosilho, 2011).

On the other hand, public-private partnerships (PPPs) were regulated in Brazil in 2004 with a distinct scope from its international acronym. While PPPs globally denote a wide range of publicprivate frameworks (Bovaird, 2004), Brazil developed the concept of PPPs as a defined advancement from the concessions structure created in 1995 (Brito and Silveira, 2005). Brazilian PPPs include two distinct organizational frameworks: the administrative concession (concessão administrativa) defines government as the only payment source to the private partner, while the sponsored concession (concessão patrocionada) allows the private partner to be paid by government as well as by PPP users' fees. PPPs are associated with major infrastructure enterprises which require large investment, such as roads and railway constructions.

BOX 1 BRAZIL'S PUBLIC-PRIVATE FRAMEWORKS'

\begin{tabular}{|c|c|c|c|c|}
\hline \multirow[b]{2}{*}{$\begin{array}{l}\text { Brazilian } \\
\text { frameworks }\end{array}$} & \multicolumn{4}{|c|}{ Public-private partnerships ${ }^{2}$} \\
\hline & Outsourcing & Concession & $\begin{array}{l}\text { PPP - Administrative } \\
\text { Concession }\end{array}$ & $\begin{array}{l}\text { PPP - Sponsored } \\
\text { Concession }\end{array}$ \\
\hline Establishing law & 8.666/1993 & $8.987 / 1995$ & $11.079 / 2004$ & $11.079 / 2005$ \\
\hline Object & $\begin{array}{l}\text { Construction enterprises, } \\
\text { services, including } \\
\text { advertising, purchases, } \\
\text { sales and leases }\end{array}$ & $\begin{array}{l}\text { Public services } \\
\text { and construction } \\
\text { enterprises, focused on } \\
\text { infrastructure provision }\end{array}$ & $\begin{array}{l}\text { Public services } \\
\text { and construction } \\
\text { enterprises, focused on } \\
\text { infrastructure provision }\end{array}$ & $\begin{array}{l}\text { Public services } \\
\text { and construction } \\
\text { enterprises, focused on } \\
\text { infrastructure provision }\end{array}$ \\
\hline
\end{tabular}

\footnotetext{
${ }^{1}$ The table presents a summary of key aspects highlighted by the author to classify four public-private contractual frameworks, leaving other important aspects without representation.

${ }^{2}$ In accordance to the usual international meaning described.
} 


\begin{tabular}{|c|c|c|c|c|}
\hline \multirow[b]{2}{*}{$\begin{array}{l}\text { Brazilian } \\
\text { frameworks }\end{array}$} & \multicolumn{4}{|c|}{ Public-private partnerships ${ }^{2}$} \\
\hline & Outsourcing & Concession & $\begin{array}{l}\text { PPP - Administrative } \\
\text { Concession }\end{array}$ & $\begin{array}{l}\text { PPP — Sponsored } \\
\text { Concession }\end{array}$ \\
\hline Time length & $0-5$ years & Unlimited & $5-35$ years & $5-35$ years \\
\hline Monetary value & Unlimited & Unlimited & At least $\mathrm{R} \$ 20$ millions & At least $\mathrm{R} \$ 20$ millions \\
\hline Payment & Fixed & Variable & Variable & Variable \\
\hline Who pays & Government & Users & Government & Government and users \\
\hline Risks & Government & Shared & Shared & Shared \\
\hline
\end{tabular}

Source: Elaborated by the author.

\section{METHODOLOGY AND DATA COLLECTION}

Based on the case study skill of congregating different information sources, this research conducted a multiple case study based on documents, reports, and interviews (Yin, 2001). This research is not a strictly qualitative or quantitative research, benefitting from these two sorts of analysis. The researcher gathered all Poupatempo outsourcing contracts and performance reports signed by Prodesp between 2010 and 2015 and UAI - Phase I contract and performance reports.

Among the analyzed information, the only one that was already publicly available was the UAI _ PPP Phase I contract (Governo do Estado de Minas Gerais, 2010a). The remaining contracts and performance reports were obtained through requests presented to the São Paulo and Minas Gerais governments made through the Access to Information Act (Lei de Acesso à Informação - LAI) (Brasil, 2011).

The developed contract analysis classified Poupatempo and UAI documents according to the same criteria. Criteria was grouped into five categories: "Contract General Data", "Object", "Payment", "Sizing" and "Risks and Penalties".

Once Prodesp, a São Paulo Government's institution, responded to the information request with 1.886.xls files with different indicators and formats, performance reports analysis demanded computational and mathematical effort. Due to verified changes over time in these reports, however, it was only possible to make a consistent examination of the last 12 months of the Poupatempo program for 57 centers. Still for this period not all data was available for every center, resulting in an average monthly sample of 683 observations for each of the seven program indicators contained in its contracts. ${ }^{3}$

The quantitative comparison between the contractual indicators of both programs was made in steps. First, a descriptive analysis of the data for each of the indicators of the two programs allowed a general picture. Further, it was possible to make a single statistical comparison using a T-Student test for the only indicator that was identical in both contracts, the satisfaction survey.

On top of the strictly formal analysis of contracts and reports, eight interviews were conducted with managers of different levels and activities of the two public policies. These interviews allowed

\footnotetext{
${ }^{3}$ Poupatempo contracts adopt five indicators, however, its performance reports decompose these into seven indicators.
} 
the gathering of agents' perception on the process and aspects of the two programs that would have been unnoticed otherwise. Once the public nomination of interviewees could set their positions at risk, each one of them is thereby identified by the surname Silva and received a name starting with letters from $\mathrm{A}$ to $\mathrm{H}$ according to the interviews chronology.

As these interviews involved experts on the studied subject, they were conducted as elite interviews (Leech, 2002). As much as possible respondents were allowed free talking (Dexter, 1970). Although scripts for semi structured were prepared with objective questions, respondents were rarely interrupted and they could explain their views freely (Leech, 2002).

\section{ECONOMIC THEORY}

Scholars debate on public delegation to private partners developed as series of opposing waves preaching the state absolute efficiency or inefficiency. Hence, theoretical debate has advised for the state's replacement by private agents or otherwise a statist view (Przeworski, 1996, 2005). Some recent economic scholars, however, relativized this analysis by seeking to study through individual situations. Thus, we address specifically some of this recent theories: transaction cost economics (Williamson, 1999, 2008, 1985), incomplete contracts (Hart, Shleifer and Vishny, 1997) and theory of incentives (Laffont and Tirole, 1993). For these three currents there is no absolute model of state efficiency or inefficiency, but levels of organization efficiency depending on the transaction to be executed.

\subsection{TRANSACTION COSTS ECONOMICS}

Transaction cost economics studies the economic cost involved in reaching an agreement, monitoring and controlling it when setting a transaction (Williamson, 1999, 2008, 1985). Transaction costs are present in all delegation of economic activity (Williamson, 1985). Its extent can justify the internalization of activities in a firm or its externalization in a market relation (Coase, 1937).

Transaction costs can be classified as ex ante and expost the start of the economic relation. Exante transaction costs are those associated with the agreement's drafting, negotiation and safeguards. In opposition, ex post transaction costs happen due to monitoring, adjusting, correcting behaviors and maintaining extra-judicial governance structures to resolve disputes (Williamson, 1985). Ex ante and ex post costs are correlated. The drafting and negotiation of a comprehensive and complex agreement that provides a range of future possibilities and allocate property rights and responsibilities can save ex post transaction costs. On the other hand, less detailed contracts allow greater room for negotiation as unforeseen situations occur, resulting in cheapening ex ante transaction costs and more expensive ex post transaction costs (Williamson, 1999, 1985).

In transaction costs economics, the key elements considered of any transaction are its frequency, asset specificity and uncertainty. Although some authors attribute most explanatory power to asset specificity, according to Williamson frequency and asset specificity would be meaningless without uncertainty as there would be no need for transaction adjustments (Williamson, 2008). Hence, according to this proposition, a transaction more susceptible to uncertainty has higher transaction costs. 
Further, transactions vulnerable to an additional risk of probity should not be contracted from a third party as they present a higher transaction cost. Probity is understood as loyalty and rectitude when providing an activity (Williamson, 1999). The risk of probity is present in every transaction but its intensity varies.

\subsection{INCOMPLETE CONTRACTS}

Foreseeing all transaction components and possible events in a contract is impossible due to bounded rationality (Hart, Shleifer and Vishny, 1997). Qualitative variables are particularly hard to be predicted in contracts leaving it more vulnerable when contracted. As cost reductions are presumed to have negative effects on quality and, quality improvements positive effects on costs, delegating qualitative transactions presents an intrinsic higher risk. This brings particular risk to delegating government activities which cannot be fully contractually described (Hart, Shleifer and Vishny, 1997). Further, unlike civil servants, private company employees have incentives to reduce costs risking quality provision, hence, adding an extra risk (Hart, Shleifer and Vishny, 1997).

On top of that, incentives that reward an agent to devote more attention to an activity or aspect of a task necessarily reduce expended attention to other jobs. For this reason, establishing an agency relationship for the provision of services with multiple objectives may be even riskier (Holmstrom and Milgrom, 1991).

\subsection{THEORY OF INCENTIVES}

Laffont and Tirole typify incentive structures in economic regulation and public procurement initiatives. In their view, public procurement occurs when government pays for the activity, being both the regulator and the buyer of that object. On the other hand, economic regulation means government does not expend resources on that private activity, but merely regulate the object leaving its citizens to purchase it. The authors consider two distinct criteria in their model: transference of public resources as compensation and incentives intensity (Laffont and Tirole, 1993).

This research's interest falls on public procurement as in both analysed cases there is transference of public funds as payment for some private activity. In this category, high intensity incentives occur in contracts where the government pays a fixed price. In these cases, the company would be the sole beneficiary of its cost reductions, as government does not remunerate according to the realized cost, but as a previously agreed price. So, in order to increase its profit, company will focus on reducing its cost. Structures with low intensity incentives occur in cost-plus contracts, in which the government pays the firm as a return margin on its incurred cost. Therefore, in cost-plus contracts a potential increase in private costs would be transferred to government. Finally, the intermediate incentive intensity occurs in contracts with incentives, in which the government and the contractor share costs or profit according to some contractual rule. 


\begin{tabular}{|c|c|c|}
\hline \multirow[b]{2}{*}{ Intensity } & \multicolumn{2}{|c|}{ Transference is allowed? } \\
\hline & $\begin{array}{c}\text { Yes } \\
\text { (contracting out, most } \\
\text { governamental iniciatives) }\end{array}$ & $\begin{array}{c}\text { No } \\
\text { (most regulated companies) }\end{array}$ \\
\hline $\begin{array}{l}\text { — Very high } \\
\text { (Company is residual claimant) }\end{array}$ & Fixed price contracts & Price limit \\
\hline $\begin{array}{l}\text { — Moderate } \\
\text { (Costs or profit division) }\end{array}$ & Contracts with incentives & Incentive regulation \\
\hline $\begin{array}{l}\text { — Very low } \\
\text { (Government or consumers are residual claimants) }\end{array}$ & Cost-plus contracts & Service costs regulation \\
\hline
\end{tabular}

Source: Laffont and Tirole (1993).

This research, therefore, seeks to empirically observe some of the highlighted theoretical propositions in the two selected cases. To facilitate this discussion, we summarize the theoretical propositions we aim to observe.

\section{BOX 3 THEORETICAL PROPOSITIONS}

P1 Complex contracts require higher ex ante transaction costs and lower ex post transaction costs

P2 Contracting similar activities result in analogous risk of probity.

P3 Property rights residual control transference to private agents provides an incentive to reduce costs, even at the expense of quality.

P4 Fixed price contracts present the private agent a stronger incentive to reduce costs even at the expense of quality

P5 With opposing goals to the principal, private agents act on unobserved variables diminishing service quality.

P6 Incentive structures are clear and comprehended by its receptors, its weight is determinant to induce private agents behavior.

Source: Elaborated by the author.

\section{CASE ANALYSIS}

\subsection{POUPATEMPO}

Established in 1997, São Paulo government's Poupatempo (Saving time) is a public policy internationally recognized for its quality standards. At the time of article's writing Poupatempo has a network of 67 
citizen service centers that deliver approximately 170 thousand services daily. Since 2007, Poupatempo has outsourced its centers to the private sector, changing deeply its working governance.

Scholars works on Poupatempo focused on its creation and the benefits it has provided to the local population (Annenberg, 2002; Paulics, 2003) or tend to develop on the cutting red tape principles that inspired it (Painelli, 2008). Up to the conducted research, only recently has Poupatempo's economic impact been analyzed (Fredriksson, 2015). As a result, over the research on this public policy the impact of the recent outsourcing strategy seems to occupy a secondary role.

Between 1997 to 2007 Poupatempo installed its first network of 10 centers which ran based on public servants. These centers were managed by the public controlled Data Processing Company of São Paulo State (Companhia de Processamento de Dados do Estado de São Paulo - Prodesp). At the program's creation, São Paulo's government had a perception of public servants excess which justified its allocation at the new Poupatempo centers (Paulics, 2003). Over its later expansion, however, this originally designed administrative model reached exhaustion (Araújo, 2009; Paulics, 2003).

Facing human resources scarcity and aiming an expansion towards the countryside, Poupatempo adopted an outsourcing strategy (Araújo, 2009). Since 2007, its network expanded from 10 to 67 centers. Therefore, Poupatempo has different management models amongst its network. The first 10 centers maintain its management policy unchanged, continuing to operate with public servants; the remaining centers, deployed along this following expansion, were named "Integrated Management Centers". Simultaneously, two other models were included in the network, the "Mobile Centers", operating inside trucks' containers, and more recently, the "Advanced Management Centers", designed in partnership with the State Traffic Department (Departamento Estadual de Trânsito - Detran). Contracts of all kinds, however, were signed by Prodesp which remains responsible for the entire Poupatempo program.

\section{TABLE 1 POUPATEMPO — CITIZEN SERVICE CENTERS BY GOVERNANCE MODEL}

\begin{tabular}{|c|c|c|c|c|}
\hline & Public Administration & $\begin{array}{l}\text { Integrated and Advanced } \\
\text { Management }\end{array}$ & Mobile & Total \\
\hline 2007 & 10 & 0 & 0 & 10 \\
\hline 2009 & 10 & 4 & 7 & 21 \\
\hline 2011 & 10 & 16 & 7 & 26 \\
\hline 2015 & 10 & 51 & 6 & 67 \\
\hline
\end{tabular}

Source: Elaborated by author based on interviews and Araújo (2009).

Regardless of the governance model to which it is associated, Poupatempo contracts are almost identical. Each contract contains the same payment formula, same time length, have very similar technical requirements and have the same quality indicators. Amongst the 49 contracts examined, 
heterogeneity was limited to: number of contracted centers; to foresee an implementation or an physical adaptation requirement or not; the set of services to be provided; quantity of working positions (postos de atendimento) to be supplied. Thus, aside from the implementation or physical adaptation requirement, the remaining variations occur due to the sizing of the comprehended centers. All documents foresaw a 60 months' contract with the exception of the three most recent ones, which foresaw a period of 48 months renewable for another 12 months.

The Poupatempo Mobile Centers have a clear contractual distinction, its physical equipment. This is the only case amongst the Poupatempo contracts in which the venue provision is contained in the contractual scope as a private obligation. Among the 49 contracts analyzed, six could be distinguished as Mobile Center contracts, each encompassing a single center. In the remaining contractual variables, however, these contracts are no different from any of its pairs. Finally, it must be safeguarded that the original Public Administration Centers follow a distinct administrative logic. Each Public Administration Center has "hundreds of contracts themselves" (Silva, 2015a). Therefore, as there is no whole public-private framework employed on Public Administration Centers, these centers are kept aside from this examination.

Amongst the analyzed Poupatempo contracts there are contracts comprehending one to five Integrated and Advanced Management centers. The sizing decision of each contract is based on each center dimension and projected demand, thus, seeking to ensure attractiveness for the bidding companies (Silva, 2015a).

The payment formula established in all contracts analyzed is essentially the same. The contract value is paid monthly by Prodesp to the private agent in equal values which may only change due to: i) implementation or physical adaptation schedule, ii) quality indicators, iii) penalties. Aside from possible schedule faults, each outsourcing contract of Poupatempo centers has the same three or four quality indicators with the same payment impact and the same goals, as well as the same foreseen penalties.

The maximum potential payment impact due to quality indicators varies from $2.25 \%$ to $3.00 \%$. This difference accrues from the presence of the indicator "Average Service Time (AST) - Driving License Issuing" as only part of the network offer this referred service. In case of repeated maximum penalties, the contractor can be fined and thus commit larger portions of their payment, or even have the contract terminated. Poupatempo contracts also provide for penalties for failure to comply with any other contractual clauses. These penalties application, however, require a lengthier procedure.

TABLE 2 POUPATEMPO — CONTRACTUAL INDICATORS

\begin{tabular}{lccc} 
Indicator & $\begin{array}{c}\text { Reference Value for } \\
\text { Total Payment }\end{array}$ & $\begin{array}{c}\text { Reference Value for } \\
\text { Maximum Penalty }\end{array}$ & Maximum Discount \\
\hline $\begin{array}{l}\text { Average Service Time (AST) — General Identity } \\
\text { Issuing }\end{array}$ & $00: 15: 38$ & $00: 16: 53$ & $0,75 \%$ \\
$\begin{array}{l}\text { Average Service Time (AST) — Driving License } \\
\text { Issuing }\end{array}$ & $00: 07: 57$ & $00: 08: 35$ & $0,75 \%$ \\
\hline
\end{tabular}




\begin{tabular}{|c|c|c|c|}
\hline Indicator & $\begin{array}{c}\text { Reference Value for } \\
\text { Total Payment }\end{array}$ & $\begin{array}{l}\text { Reference Value for } \\
\text { Maximum Penalty }\end{array}$ & Maximum Discount \\
\hline Monthly Satisfaction Survey & 9,23 & 9,04 & 0,5 \\
\hline \multicolumn{4}{|l|}{ Active service positions } \\
\hline a) Active supplied service positions, and & $100 \%$ & $99,99 \%$ & \\
\hline b) Waiting time below 20 minutes & $80 \%$ & $79,90 \%$ & $1 \%$ \\
\hline
\end{tabular}

Source: Elaborated by the author. ${ }^{4}$

\subsection{UNIDADES DE ATENDIMENTO INTEGRADO (UAI)}

UAI was created in 2007 within the e-government policy captained by the Minas Gerais' Planning and Management Department (Secretaria de Planejamento e Gestão - Seplag). UAI was planned amongst the administrative reform plan known as Management Shock (Choque de Gestão). Starting in 2003, Choque de Gestão aimed to develop Minas Gerais state from a burocratic model to a result based administration (Sousa et al., 2012). Within this reform plan, UAI's objective was to replace the Minas Gerais government former citizen service center program named Office of Integrated Urban Service (Posto de Serviço Integrado Urbano - Psiu).

As any OSS program, Psiu worked since 1996 gathering various public agencies in one place. However, it had operational difficulties that could lead to queues of five to six hours and lack of queuing tickets for distribution (Majeed, 2014). A consultancy firm also was hired to diagnose Psiu status and suggest an improvement plan which ended proposing a large restructuring recommendation (Sousa et al., 2012).

UAI's strategy to overcome Psiu's difficulties was based on labor substitution: replacement of public servants for workers hired by a public controlled company, Minas Gerais Services and Management (Minas Gerais Administração e Serviços - MGS). This working force was selected by public contest and hired though common Brazilian labor laws rather than standard civil service legislation. ${ }^{5}$ Between 2007 and 2010, UAI centers based on the MGS model replaced 22 Psiu centers (Governo do Estado de Minas Gerais, 2013).

Allied to the Choque de Gestão polices, in 2009, however, SEPLAG received a new political command. Its objective turned to substitute the remaining PSIU and the recent MGS model by a PPP. This incoming order was financially and politically motivated. Financially, PSIU had expanded its expenses faster than the state had increased its budget. Politically, the government's PPP program was amongst its political highlights and UAI could add significantly to its portfolio at the coming election. Ideally, the PPP could generate better value for money, administrative flexibilities for the program execution deriving from private managers and standardization of services provision (Sousa et al., 2012)

\footnotetext{
4 "Reference for Total Payment" and "Reference for Maximum Penalty" values represent the most recent values contained in the analyzed contracts.

${ }^{5}$ MGS hires employees though the Consolidation of Labor Laws (Consolidação das Leis do Trabalho - CLT).
} 
The UAI - PPP Phase I was signed in 2010. It is the first PPP on citizen service centers in Brazil and encompassed 6 centers of UAI's network of 30 units. Phase I should have been the first of three PPPs that would cover UAI's entire network. Phase II divided 23 remaining centers in three lots that would be proposed separately, while Phase III encompassed only UAI - Praça Sete, the program main center at the state capital. Yet, before the PPP Phase II and III could come operational, government suspended it.

\section{TABLE 3 UNIDADES DE ATENDIMENTO INTEGRADO — CITIZEN SERVICE CENTERS BY GOVERNANCE MODEL}

\begin{tabular}{l|cccc} 
& PSIU & MGS & PPP & TOTAL \\
\hline 2007 & 24 & 2 & 0 & 26 \\
2008 & 18 & 10 & 0 & 28 \\
2009 & 10 & 18 & 0 & 28 \\
2010 & 7 & 22 & 0 & 29 \\
2011 & 2 & 22 & 5 & 29 \\
2012 & 2 & 22 & 6 & 30 \\
2013 & 2 & 22 & 6 & 30 \\
\hline
\end{tabular}

Source: Adapted from Majeed (2014) and Agência Minas (2011).

UAI - PPP Phase I is an administrative concession in which, as stated in its creation law (Brasil, 2004), the private partner is not paid directly by the service's user, being the government its primary payer. Beyond the pecuniary payment, the only possible private source of income is the generation of parallel initiatives resulting in supplementary incomes. The analyzed contract foresees a 20 years partnership and comprehends $\mathrm{R} \$ 311,121,048.00$ to be paid by the Minas Gerais government as pecuniary payment.

Besides operating the six contracted centers the private partner is also responsible for implementing each of them. This task has to meet a number of requirements, as not installing centers in public buildings. On the other hand, when establishing each center the private partner is allowed certain flexibility to optimize its business. UAI - PPP Phase I, therefore, comprises a build-operate-transfer - BOT PPP (Yescombe, 2007). In this model, the private partner can maximize their performance during operation through investments in construction that make the future operation more efficient (Hart, 2003; Yescombe, 2007).

On top of implementing and running the six centers, the private partner has to scale its structure and its staff for the predicted demand. The contract establishes a "predicted demand for each center" and a "predicted growth rate of demand" for each of the 20 partnership years (Governo do Estado de 
Minas Gerais, 2010b). It also sets a minimum number of positions to be offered at each center, but does not establish an expected number of positions.

The contract only provides for renegotiation if the held demand exceed by more than $50 \%$ the projected demand. The increased demand, however, is of direct interest of the partner as its payment is directly linked to it.

\section{DISCUSSION}

\subsection{PAYMENT}

The most distinctive aspect of the analyzed cases' is its payment formula. While Poupatempo establishes a single payment mechanism, UAI - PPP Phase I provides three different components. Poupatempo's payment occurs as a simple total contract value division into monthly installments. These installments may change due to two factors: contractual indicators and the breach of contractual clauses. The maximum possible variation due to contract indicators is $3.00 \%$. On the other hand, Poupatempo's penalties can be severe, reaching $20 \%$ of the payment or even $30 \%$ in the event of unilateral termination of the contract, and when there are phases of implementation or real state adaptation can lead to payments suspension.

On the other hand, UAI's PPP main remuneration is the monthly payment for service which is calculated depending on the amount of citizens attended at the centers. Thus, UAI's payment is necessarily variable over time. However, this variation becomes greater as $40 \%$ of this amount is bound to the coefficient of efficiency, which comprises three contractual indicators. Still, as the main partner of the remuneration is a function of demand, if demand falls significantly below projection comes to place the second payment mechanism, the additional installment to compensate for this unpredicted loss. Finally, although small compared to the other two, ancillary income is foreseen and can be explored by the private partner autonomously.

When establishing Poupatempo centers with a 97\% fixed payment, São Paulo opted for a near fixed price contracts with a strong incentive structure. Minas Gerais, in opposition, has settled a contract with incentives as the government shares costs and revenues generated by the consortium (Laffont and Tirole, 1993).

Thus, the weight attributed by Minas Gerais government to rewards and contingencies is much higher than that did São Paulo government establishing an almost fixed remuneration. Minas Gerais have, therefore, sought to converge goals with the private partner.

However, although UAI's private partner manager considers its main goal "to provide 100\% of the government wishes" (Silva, 2015g), government managers identified money and profits as its partner's main driver (Silva, 2015b, 2015c, 2015f). Interviewees' contrasting statements are possibly associated with the company's effort to increase its revenue and profit.

UAI Phase I partner has focused on increasing its centers' demand resulting in a moral hazard situation (Laffont and Tirole, 1993). Although the impact of a sharp increase in demand generates a heavy burden on government's finance, amongst the PPP contractual objectives one reads "expanding the number of USERS, expansion and modernization of REVERSABLE GOODS, to adequately meet 
DEMAND" (Governo do Estado de Minas Gerais, 2010a). So, even though government explicitly wishes through its contract to increase the number of citizens attended in the PPP, it has a counter incentive to increase PPPs demand in the short run due to budget restrictions.

\section{BOX 4}

\section{UNIDADES DE ATENDIMENTO INTEGRADO (UAI) — PAYMENT FORMULA SYNTHESIS}

\begin{tabular}{|c|c|c|c|c|c|c|}
\hline Payment & Who pays & Frequency & Requirement & Quality Indicator & Weight & Claimant \\
\hline $\begin{array}{l}\text { Pecuniary payment } \\
\text { — according to } \\
\text { demand }\end{array}$ & Government & Monthly & $\begin{array}{l}\text { First center } \\
\text { operation }\end{array}$ & $\begin{array}{l}\text { Coefficient of efficiency (Coef): } \\
\text { — Satisfaction Survey (GS) } \\
\text { — Average Waiting Time } \\
\text { (AWT) } \\
\text { — Attended Passwords }\end{array}$ & $\begin{array}{l}20 \% \\
16 \% \\
4 \%\end{array}$ & Private partner \\
\hline $\begin{array}{l}\text { Pecuniary payment } \\
\text { — Additional } \\
\text { installment }\end{array}$ & Government & $\begin{array}{l}\text { Conditional } \\
\text { to demand }\end{array}$ & $\begin{array}{l}\text { Six centers } \\
\text { operation }\end{array}$ & $\begin{array}{l}\text { Coefficient of efficiency (Coef): } \\
\text { — Satisfaction Survey (GS) } \\
\text { — Average Waiting Time } \\
\text { (AWT) } \\
\text { — Attended Passwords }\end{array}$ & $\begin{array}{l}20 \% \\
16 \% \\
4 \%\end{array}$ & Private partner \\
\hline $\begin{array}{l}\text { Accessory and } \\
\text { supplementary } \\
\text { income }\end{array}$ & $\begin{array}{l}\text { Other } \\
\text { companies }\end{array}$ & Monthly & $\begin{array}{l}\text { Private } \\
\text { partner } \\
\text { sign its own } \\
\text { contracts } \\
\text { with third } \\
\text { parties }\end{array}$ & $\mathrm{N} / \mathrm{A}$ & $\mathrm{N} / \mathrm{A}$ & $\begin{array}{l}-75 \% \text { Private } \\
\text { partner } \\
-25 \% \\
\text { Government }\end{array}$ \\
\hline
\end{tabular}

Source: Elaborated by the author.

Meanwhile, the generation of ancillary revenues is a contractual prerogative of the private partner and does not present government any burden. On the contrary, government has the right to share the income generated. The two remaining possible factors through which private partner can increase its revenue and profit are to reduce costs and increase its score on the Coef. These two factors present the classic cost and quality tradeoff (Hart, Shleifer and Vishny, 1997).

In contrast, Poupatempo contractors have only $3.00 \%$ of its revenue depending on performance and have no other way to increase revenue rather than contractual expansions. Contractual expansions, however, imply negotiations and monitoring and thus high transaction costs (Williamson, 1976). So, to maximize profit these companies are left with the option of obtaining maximum score in contractual indicators and reducing costs. Reducing costs once again brings up the tradeoff between cost and quality.

\subsection{DEMAND RISK}

UAI - PPP Phase I private partner states: "[its] main risk is the risk of demand" (Silva, 2015g). According to an interviewed private manager, its infrastructure and staff are sized for an estimated 
demand that did not yet materialize. Its cost, therefore, would be unnecessarily high (Silva, 2015g). Regardless of the current situation, it is not hard to imagine factors that could occur with considerable impact on demand and apparently not taken into account in the demand projection. Demand risks, as the creation of a website for government's services, become more relevant in a 20 years perspective. However, contractual demand projection is linear over the partnership's 20 years and was exclusively based on demographic data (Governo do Estado de Minas Gerais, 2010b). Thus, although asymmetrically shared in favor of the private partner through payment compensation, risk of demand appears to be mainly falling on the private partner's side.

In contrast, Poupatempo risk of demand rests exclusively on government. Increase in demand would reduce the average payment per service but contractors would not have to resize its centers unless an extra contractual amendment requires. Decrease in demand would result in a higher average value per service but companies would not be allowed to reduce its available capacity. Thus, with companies being paid by an almost fixed value throughout the contract, the demand risk falls with government, as it may have hired an excess or a shortage and will have to incur in additional cost to resize it.

\subsection{SCOPE AND PROBITY}

Despite the highlighted similarities between the contracted objects in both selected cases, the delegation strategies do not have identical scopes. São Paulo government chose to contract management, operation and maintenance of Poupatempo centers and, in some cases, implementation. In opposition, Minas Gerais government opted for a public-private partnership comprehending implementation, operation and some apparently secondary activities.

Although, both cases contracted centers installation, Poupatempo installs its contracted centers exclusively in public facilities provided by government. UAI, in turn, forbids its private partner to install centers in public buildings. Therefore, UAI - PPP Phase I transferred to the private partner the responsibility for providing venues for its centers.

Among the activities at first seen as secondary, UAI's PPP contracted out the infrastructure provision for information technology (Governo do Estado de Minas Gerais, 2010c). Unlike the remaining UAI network, UAI PPP's centers electronic operation occurs out of government information servers. When operating in its own servers the private partner has been accused of manipulating data in its favor. This allegedly manipulation may have been an improbity case. Further, as the private partner was operating the public activity away from government's eyes, the information asymmetry led this potential manipulation to last longer before been noticed (Silva, 2015b).

The described events allow us to state that Proposition 2: contracting similar activities result in analogous risk of probity was not observed empirically.

\subsection{CONFLICT RESOLUTION}

Over this research, it could be identified in the UAI - PPP Phase I that conflicts between public and private goals led the parties to use the conflict resolution structures planned on its contract. UAI's contract predicted a framework to resolve disputes ex post the beginning of the transaction on 
variables not contracted or on which there could be disagreement. Due to this extra-judicial conflict resolution instrument, the PPP's was not taken to court, avoiding further escalation.

Poupatempo's contracts, on the contrary, do not provide a similar conflict resolution framework and predicts that all controversies lead to penalties and can further be taken to court. This is a clear example where a more detailed contract that incurred a high cost of transaction ex ante abdicated of a mechanism for resolving disputes ex post. Thus, Proposition 1: Complex contracts require higher ex ante transaction costs and lower ex post transaction costs was observed in the analyzed cases.

\subsection{MORAL HAZARD}

The antagonism between São Paulo and Minas Gerais governments' goals and their private partners is self-evident. Public managers are aiming for the service's best quality at the lowest cost, in opposition, private managers seek to increase profit and revenue. UAI - PPP Phase I brings a higher moral hazard risk due to its payment formula linking private partner's remuneration to held demand. Increasing its centers' demand has become the central objective of the private partner, while government seeks to keep demand matching its budget. In Poupatempo the moral hazard falls on encouraging the contractor to reduce costs, while government objects provide citizens with the best quality service.

It has been found that UAI's private partner adopted initiatives to autonomously increase the number of citizens demanding its centers. First, it suggested the anticipation of UAI's opening hours (Silva, 2015b). This proposition had to be authorized by the government, since it was not foreseen in contract clauses. Simultaneously, without SEPLAG's awareness, the private partner reached out for other public agencies offering to dispose more services in UAI's network (Silva, 2015f).

UAI's PPP, therefore, presents a moral hazard situation as the private agent driven by its goal acted on unobserved variables with adverse effects to the principal's objectives. This brought losses to the government's budget and harmed its goal. Thus, Proposition 5: with opposing goals to the principal, private agents act on unobserved variables diminishing service quality was observed in the analyzed cases.

\subsection{SERVICE QUALITY}

Poupatempo's contractors are paid with a fixed price contract with a low weight given to quality indicators. Thus, these contracts present a strong incentive to reduce private costs. On the other hand, the private partner of the UAI's PPP deals with a contract with incentives, with $40 \%$ of the main monthly payment associated with quality indicators. Therefore, UAI's private partner, although seeking to reduce costs, has high-stakes at low scores on quality contractual indicators. Looking strictly to contractual performance indicators for the year 2015, it is possible to conclude that the PPP's private partner maintained a sound performance. ${ }^{6}$

\footnotetext{
${ }^{6}$ Although the request presented to the Minas Gerais government asked for data for the longest period available, performance information was only sent regarding 2015 .
} 
RAP | An analysis of public-private partnership contractual incentives in Brazilian citizen service centers

\section{TABLE 4 UAI — DESCRIPTIVE STATISTIC ON CONTRACTUAL INDICATORS}

\begin{tabular}{|c|c|c|c|c|}
\hline & SATISFACTION SURVEY & WAITING TIME & ATTENDED PASSWORDS (\%) & COEF \\
\hline Reference value & $95 \%$ & 00:08:00 & $92 \%$ & 1 \\
\hline Mean & $98,69 \%$ & 00:06:40 & $97,21 \%$ & 0,99 \\
\hline Median & $98,93 \%$ & 00:06:16 & $97,14 \%$ & 1 \\
\hline Stand. deviation & $0,85 \%$ & $00: 02: 14$ & $1,06 \%$ & 0,03 \\
\hline Coef. of variation & $0,86 \%$ & $36,00 \%$ & $1,09 \%$ & $3,00 \%$ \\
\hline Number of offenses & - & 10,00 & - & 10,00 \\
\hline Number of offenses (\%) & $0 \%$ & $15 \%$ & $0 \%$ & $15 \%$ \\
\hline Sample & 66 & 66 & 66 & 66 \\
\hline
\end{tabular}

Source: Elaborated by the author based on Minas Gerais government data.

\section{TABLE $5 \quad$ UAI — COEFFICIENT OF EFFICIENCY}

\begin{tabular}{lcccccc} 
& BETIM & GOV. VALADARES & JUIZ DE FORA & MONTES CLAROS & UBERLÂNDIA & VARGINHA \\
\hline jan-15 & 1,00 & 1,00 & 1,00 & 0,84 & 1,00 & 1,00 \\
fev-15 & 0,92 & 1,00 & 1,00 & 1,00 & 1,00 & 1,00 \\
mar-15 & 0,92 & 1,00 & 1,00 & 0,92 & 1,00 & 1,00 \\
abr-15 & 0,92 & 1,00 & 1,00 & 0,92 & 1,00 & 1,00 \\
mai15 & 0,92 & 1,00 & 0,92 & 0,92 & 1,00 & 1,00 \\
jun-15 & 1,00 & 1,00 & 1,00 & 0,92 & 1,00 & 1,00 \\
jul-15 & 1,00 & 1,00 & 1,00 & 1,00 & 1,00 & 1,00 \\
ago-15 & 1,00 & 1,00 & 1,00 & 1,00 & 1,00 & 1,00 \\
set-15 & 1,00 & 1,00 & 1,00 & 1,00 & 1,00 & 1,00 \\
out-15 & 1,00 & 1,00 & 1,00 & 1,00 & 1,00 & 1,00
\end{tabular}

Source: Elaborated by the author based on Minas Gerais government data.?

\footnotetext{
${ }^{7}$ Highlighted values represent Coef at levels below the maximum value (1.00).
} 
On the other hand, when analyzing Poupatempo data on contractual indicators, it is possible to note that the number of offenses is higher than UAI's. However, it is worth noticing that besides observing Poupatempo for 12 months, there are 57 centers in the analyzed sample, almost 10 times the amount of UAI centers considered. ${ }^{8}$ Nevertheless, while UAI - PPP Phase I focuses its offenses in a single contractual, Poupatempo centers have committed offences over all its indicators.

Contrasting three of the six UAI - PPP Phase I centers committed offences, $50 \%$ of the PPP's centers, in Poupatempo 43 of the 57 Poupatempo centers committed offences, or $75 \%$ of the sampled centers. Furthermore, Poupatempo presents a higher coefficient of variation. Therefore, through the analysis of the contractual indicators it is possible to notice that by distributing its centers in several contracts, São Paulo government has led to performance heterogeneity on its centers' performances.

\section{TABLE 6 POUPATEMPO — DESCRIPTIVE STATISTIC ON CONTRACTUAL INDICATORS}

\begin{tabular}{|c|c|c|c|c|c|c|c|}
\hline & $\begin{array}{l}\text { SATISFACTION } \\
\text { SURVEY }\end{array}$ & $\begin{array}{c}\text { AWT — GE- } \\
\text { NERAL ID }\end{array}$ & $\begin{array}{l}\text { AWT — DRI- } \\
\text { VING LICENCE }\end{array}$ & $\begin{array}{c}\text { AWT — WORKING } \\
\text { PERMIT }\end{array}$ & $\begin{array}{l}\text { AST —GE- } \\
\text { NERAL ID }\end{array}$ & $\begin{array}{l}\text { AST — DRI- } \\
\text { VING LICENCE }\end{array}$ & $\begin{array}{c}\text { ACTIVE } \\
\text { POSITIONS }\end{array}$ \\
\hline $\begin{array}{l}\text { Reference } \\
\text { value }\end{array}$ & 9,23 & 00:20:00 & 00:20:00 & 00:20:00 & 00:15:38 & 00:08:02 & $80 \%$ \\
\hline Mean & 9,79 & 00:06:31 & 00:06:42 & 00:10:16 & 00:11:19 & 00:06:51 & $101 \%$ \\
\hline Median & 9,83 & 00:04:46 & 00:06:06 & 00:06:14 & 00:11:21 & 00:06:53 & $101 \%$ \\
\hline $\begin{array}{l}\text { Standard } \\
\text { deviation }\end{array}$ & 0,18 & 00:05:31 & 00:04:00 & 00:12:46 & 00:02:24 & 00:01:24 & $12 \%$ \\
\hline $\begin{array}{l}\text { Coefficient of } \\
\text { variation }\end{array}$ & $2 \%$ & $85 \%$ & $60 \%$ & $124 \%$ & $21 \%$ & $20 \%$ & $12 \%$ \\
\hline $\begin{array}{l}\text { Num. } \\
\text { offenses }\end{array}$ & 2 & 10 & 9 & 45 & 25 & 86 & 26 \\
\hline $\begin{array}{l}\text { Num. } \\
\text { offenses (\%) }\end{array}$ & $0 \%$ & $2 \%$ & $1 \%$ & $12 \%$ & $4 \%$ & $15 \%$ & $5 \%$ \\
\hline Sample & 639 & 530 & 612 & 369 & 571 & 567 & 524 \\
\hline
\end{tabular}

Source: Elaborated by the author based on São Paulo government data. ${ }^{9}$

Contrasting UAI's PPP constantly close to the ideal indicators to Poupatempo's higher variance and proportionally higher number of offences, it is possible to conclude that both programs' agents understood its contractual incentive structures. Agents have modeled their behavior based on its indicators and associated weight. Thus, Proposition 6: incentive structures are clear and comprehended

\footnotetext{
${ }^{8}$ Due to data format, not all Poupatempo centers could be considered in every indicator. Further, there are centers that do not offer all the services offered in Poupatempo and, therefore, could not be analyzed in every contractual indicator.

9 "Reference value" for AST - General Identity and AST - Driving Licence Issuing have been updated in the analysed contracts since 2015. Therefore, we adopted the values contained in the Management Reports (Relatórios Gerenciais) provided by Prodesp.
} 
by its receptors, its weight is determinant to induce private agents behavior could be observed in the analyzed cases.

\subsection{PERFORMANCE COMPARISON}

Contractual indicators presented by the two public policies allow us few direct comparisons as, although similar in nature, there are differences between them. Poupatempo, for example, adopts indicators of active positions and average service time (AST) that are not present in UAI - PPP Phase I. In turn, UAI implements an indicator on attended passwords which is not present in Poupatempo's contracts.

As for the average waiting time (AWT), indicators although similar, keep slight differences that could lead a simple statistical analysis to error. In order to compare it would be necessary to consider as equal the UAI's AWT and the Poupatempo's AWT - General Identity and AWT - Driving License. The comparison, therefore, would contrast the average waiting time for all UAI centers' services to a couple of Poupatempo's services. Still, even as the Poupatempo draws the a 20-minute limit as a benchmark for AWT - General Identity and Driving License services, its centers run an average indicator of $6 \mathrm{~min} 31 \mathrm{~s}$ and $06 \mathrm{~min} 42 \mathrm{~s}$, respectively. On the other hand, UAI settles a more strict reference value, $8 \mathrm{~min}$, but its PPPs centers run at an average AWT of 6min40s. Hence, despite the limitation of this comparison, there seems to be a performance similarity between both programs at this indicator.

In broad terms, it seems that the contractual indicators measured in UAI - PPP Phase I and in Poupatempo's contracts are in line with the good public reputation of these policies. In average both cases set of indicators exceed reference values. It claims attention, however, that Poupatempo contracts set less rigorous reference values than UAI's. This statement can be illustrated by the indicators that appear in both programs AWT and the Satisfaction Survey. Nevertheless, Poupatempo's AST and Active Positions indicators account for most of the verified offences, and might, therefore, have strict reference values. It is not possible to draw statements on this subject as UAI does not present a counterpart for these indicators.

Mathematical comparison of Poupatempo and UAI's Satisfaction Survey is the only one possible among all indicators presented. This happens as both indicators measure the exact same phenomenon: the general satisfaction of the service's users. In both cases, services' users are requested to answer satisfaction surveys. Further, coincidentally, these indicators have the maximum contractual weights of their contracts, $50 \%$ of Coef in UAI and 1\% Poupatempo's monthly installment. The heavy weight attributed is probably due to its broad character of its measurement and its link to the government's objective users satisfaction.

Hence, looking forward to make a statistical comparison that could show whether the difference between the programs indicators was significant, it was possible to run a T-Student test. The test compared 66 observations on the UAI - PPP Phase I Satisfaction Survey with 639 observations of Poupatempo's Satisfaction Survey, both taken from the same period of time.

Though both programs are highly rated by its users, the test resulted in a statistic relevant difference of 0.747 between both means. Moreover, as in other indicators, it is clear that Poupatempo centers have a higher variance in performance. However, since it has been contrasted the only UAI - PPP Phase I contract run by a single company with many Poupatempo contracts run by multiple firms it 
is reasonable set this result under the limit enquire of whether this difference would keep significant if there were more contracts observed in Minas Gerais or fewer cases in São Paulo.

\section{TABLE $7 \quad$ T-STUDENT TEST ON UAI AND POUPATEMPO SATISFACTION SURVEY WITH DIFFERENT VARIANCE SAMPLES}

\begin{tabular}{lcc} 
& UAI & POUPATEMPO \\
Mean & 98,68787879 & 97,94053208 \\
Variance & 0,7366262 & 3,179718212 \\
Sample & 66 & 639 \\
Mean difference hypothesis & 133 & \\
Gl & 5,883144872 \\
Stat $t$ & $1,54548 \mathrm{E}-08$ \\
$\mathrm{P}(\mathrm{T}<=\mathrm{t})$ unicaudal & 1,656391244 \\
$\mathrm{t}$ criteria unicaudal & $3,09095 \mathrm{E}-08$ \\
$\mathrm{P}(\mathrm{T}<=\mathrm{t})$ bicaudal & 1,977961264 \\
$\mathrm{t}$ criteria bicaudal & & \\
\hline
\end{tabular}

Source: Elaborated by the author.

Although users' satisfaction on UAI - PPP Phase I is higher than the ratings given by Poupatempo's users, both programs users' average satisfaction demonstrate the good performance of the private agents. Hence, based on all contract indicators we cannot state that the private agents's actions to reduce costs have significantly diminished service quality. Caring for quality service collides with the expected contractors' behavior, especially in Poupatempo. With fixed price contracts, Poupatempo's contractors were theoretically expected to have strong incentive to reduce costs and, consequentially, quality (Laffont and Tirole, 1993). This conclusion was also supported by interviewees, who presented no criticism of cost reduction at quality expenses. Therefore, with the available contractual indicators, it is not possible to observe Proposition 3: property rights residual control transference to private agents provides an incentive to reduce costs, even at the expense of quality. This conclusion, however, is limited as it is notable that OSS model citizen service centers in Brazil are well evaluated by its users (Ferrer, 2012).

The T-student test results, on the other hand, are in line with theoretical expectation, as Poupatempo contracts with fixed price have stronger incentive towards cost reduction than UAI - PPP Phase I contract. Therefore, Proposition 4: fixed price contracts present the private agent a stronger incentive to reduce costs even at the expense of quality could be observed. 


$\begin{array}{lll}\text { P1 } & \text { Complex contracts require higher ex ante transaction costs and lower ex post transaction costs } & \text { Observed } \\ \text { P2 } & \text { Contracting similar activities result in analogous risk of probity. } & \text { Not observed } \\ \text { P3 } & \begin{array}{l}\text { Property rights residual control transference to private agents provides an incentive to reduce } \\ \text { costs, even at the expense of quality. }\end{array} & \text { Not observed } \\ \text { P4 } & \begin{array}{l}\text { Fixed price contracts present the private agent a stronger incentive to reduce costs even at } \\ \text { the expense of quality }\end{array} & \text { Observed } \\ \text { P5 } & \begin{array}{l}\text { With opposing goals to the principal, private agents act on unobserved variables diminishing } \\ \text { service quality. }\end{array} & \text { Observed } \\ \text { P6 } & \begin{array}{l}\text { Incentive structures are clear and comprehended by its receptors, its weight is determinant } \\ \text { to induce private agents behavior. }\end{array}\end{array}$

Source: Elaborated by the author.

\section{CONCLUSION}

The research methodology combined with the theoretical background successfully explains the encountered phenomena in the UAI - Phase I. Given the contractual incentives clarity and the relevance it is given by the incentive sender, the private partner shaped its actions accordingly. Thus, it has been able to perform well in the indicators over the analyzed period. The aspect that claimed most attention over this case analysis, however, was to have the private partner's largest remuneration proportional to users demand. This equation is risky as one considers the PPP length, thus, generating a high transaction cost. In the same way, the PPP transference of services that go beyond the citizen service center operation also proved to be a challenge for the project. This transference led to an allegedly risk of probity.

Oppositely, the adopted theoretical background was not fully able to explain Poupatempo's good performance. These citizen service centers were contracted out on a fixed-price payment basis which theoretically produces strong incentives to reduce costs and consequentially quality. This expected quality diminish, however, empirically did not reflect in a concern as Poupatempo performance remained well evaluated by its contract indicators.

A hypothesis to be further investigated for Poupatempo's quality could be the role of the public servants on the centers ground (Cabral, Lazzarini and Azevedo, 2010). However, it is known that these public employees do not perform a monitoring role once again challenging theory. 


\section{REFERENCES}

AGÊNCIA MINAS. Estado fecha 2011 com 28 unidades de atendimento integrado em funcionamento. Available at: <www.ppp.mg.gov.br/noticias-uai/ page/587-estado-fecha-2011-com-28-unidadesde-atendimento-integrado-em-funcionamento $>$. Accessed on: 24 Jan. 2016.

ANNENBERG, Daniel. Diretrizes e estratégias para a implantação e manutenção de um padrão de qualidade na prestação de serviços públicos: a experiência paulista do Poupatempo. In: CONGRESO INTERNACIONAL DEL CLAD SOBRE LA REFORMA DEL ESTADO Y DE LA ADMINISTRACIÓN PÚBLICA, 8., 2002. Lisboa. Anais... Lisbon: Clad, 2002.

ARAÚJO, Alexandre. O Poupatempo e sua nova forma de gestão. In: FÓRUM INTERNACIONAL DAS CENTRAIS DE ATENDIMENTO INTEGRADO, 2009, Brasília. Anais... Brasília: Ministério do Planejamento, 2009.

ASKIM, Jostein et al. One-stop shops for social welfare: the adaptation of an organizational form in three countries. Public Administration, v. 89, n. 4, p. 1451-1468, 2011.

BOVAIRD, Tony. Public-private partnerships: from contested concepts to prevalent practice. International Review of Administrative Sciences, v. 70, n. 2, p. 199-215, June 2004.

BRASIL. Lein. 11.079 - Lei de PPPs. 2004. Available at: <www.planalto.gov.br/ccivil_03/_ato20042006/2004/lei/111079.htm>. Accessed on: 21 May 2017.

BRASIL. Lei 12.527 - Lei de Acesso à Informação. 2011. Available at:<www.planalto.gov.br/ccivil_03/_ ato2011-2014/2011/lei/112527.htm>. Accessed on: 21 May 2017.

BRITO, Barbara M. B.; SILVEIRA, Antonio H. P. Parceria público privada: compreendendo o modelo brasileiro. Revista do Serviço Público, v. 56, n. 1, .7-21, 2005.

CABRAL, Sandro; LAZZARINI, Sergio; AZEVEDO, Paulo F. Private operation with public supervision: evidence of hybrid modes of governance in prisons. Public Choice, v. 145, n. 1, p. 281-293, 2010.

COASE, Ronald H. The nature of the firm. Economica, v. 4, n. 16, p. 386-405, 1937.
DEXTER, Lewis A. Elite and specialized interviewing. Evanston: Northwestern University Press, 1970.

FERRER, Florencia. Políticas e modelos de atendimento ao cidadão no Brasil. In: BANCO INTERAMERICANO DE DESENVOLVIMENTO (Org.). Apoio à Preparação de um Programa Nacional de Fortalecimento do Planejamento e Gestão Pública dos Estados Brasileiros. São Paulo, 2012.

FREDRIKSSON, Anders. Citizen service centers in Brazil - evidence from the Poupatempo Reform. Cors - Center for Organization Studies, 2015.

GONÇALVES, Emilia M. Processo de difusão das Unidades de Atendimento Integrado: o caso do Serviço de Atendimento ao Cidadão. In: CONGRESO INTERNACIONAL DEL CLAD SOBRE LA REFORMA DEL ESTADO Y DE LA ADMINISTRACIÓN PÚBLICA, 8., 2003, Panamá. Anais... Panama: Clad, 2003.

GOVERNO DO ESTADO DE MINAS GERAIS. Contrato de Concessão UAI - Contrato de Concessão Administrativa para Implantação, Operação, Manutenção e Gestão de Unidades de Atendimento Integrado (UAI) No 9001375/2011. Belo Horizonte, 2010a.

GOVERNO DO ESTADO DE MINAS GERAIS. UAI - Apêndice I - Demanda Projetada UAI - Contrato de Concessão Administrativa para Implantação, Operação, Manutenção e Gestão de Unidades de Atendimento Integrado (UAI) No 9001375/2011. Belo Horizonte, 2010b.

GOVERNO DO ESTADO DE MINAS GERAIS. UAI - Termo de Referência UAI - Contrato de Concessão Administrativa para Implantação, Operação, Manutenção e Gestão de Unidades de Atendimento Integrado (UAI) No 9001375/2011. 2010c.

GOVERNO DO ESTADO DE MINAS GERAIS; UAI, U. DE A. I. - Atendimento ao cidadão: 10 anos choque de gestão. Belo Horizonte, abr. 2013.

HART, Oliver. Incomplete contracts and public ownership: remarks, and an application to publicprivate partnerships. The Economic Journal, v. 113, n. 486, p. c69-c76, 2003.

HART, Oliver; SHLEIFER, Andrei; VISHNY, Robert. The proper scope of government: theory and an application to prisons. The Quarterly Journal of Economics, v. 112, n. 4, p. 1127-1161, 1997. 
HOLMSTROM, Bengt; MILGROM, Paul. Multitask principal-agent analyses: incentive contracts, asset ownership, and job design. Journal of Law, Economics and Organization, v. 7, Jan. 1991.

LAFFONT, Jean-Jacques; TIROLE, Jean. A theory of incentives in procurement and regulation. Cambridge: MIT Press, 1993.

LEECH, Beth L. Asking questions: techniques for semistructured interviews. PS: Political Science and Politics, v. 35, n. 4, p. 665-668, 2002.

MAJEED, Rushda. A second life for one-stop shops: citizen services in Minas Gerais, Brazil, 2003-2013. In: PRINCETON UNIVERSITY (Org.). Innovations for successful societies. Princeton: Princeton University, 2014.

PAINELLI, Sérgio. Poupatempo: um programa de atendimento ao cidadão. 2008. 128 f. Dissertação (mestrado em administração) - Pontifícia Universidade Católica de São Paulo, São Paulo, 2008.

PAULICS, Veronika. PoupaTempo: Central de Atendimento ao Cidadão. In: LOTTA, Gabriela S. et al. (Org.). 20 Experiências de gestão pública e cidadania. São Paulo: Programa Gestão Pública e Cidadania, 2003. p. 272-291.

PÉRICO, Ana E.; APARECIDA, Daisy. Desafios das parcerias público-privadas (PPPs). Revista de Administração Pública, Rio de Janeiro, v. 39, n. 5, p. 1031-1051, 2005.

PRZEWORSKI, Adam. Nota sobre o Estado e o mercado. Revista de Economia Política, v. 16, n. 3, p. 115-120, 1996.

PRZEWORSKI, Adam. Sobre o desenho do Estado: uma perspectiva agent $\times$ principal. In: BRESSERPEREIRA, Luiz Carlos; SPINK, Peter K. (Org.) Reforma do Estado e administração pública gerencial. Rio de Janeiro: FGV, 2005.

RIBEIRO, Mauricio P. Concessões e PPPs: melhores práticas em licitações e contratos. São Paulo: Atlas, 2011.

ROSILHO, André J. Qual é o modelo legal das licitações no Brasil? As reformas legislativas federais no sistema de contratações públicas. Thesis (Master Degree in Law) - Fundação Getulio Vargas, São Paulo, 2011.

SILVA, Ana da. Entrevista Ana da Silva (Entrevistador: André S. Avrichir). São Paulo, 2015a.
SILVA, Bruna da. Entrevista Bruna da Silva (Entrevistador: André S. Avrichir). Belo Horizonte, 2015b.

SILVA, Cintia da. Entrevista Cintia da Silva (Entrevistador: André S. Avrichir). 2015c.

SILVA, Esther da. Entrevista Esther da Silva (Entrevistador: André S. Avrichir). Belo Horizonte, 2015d.

SILVA, Fabiana da. Entrevista Fabiana da Silva (Entrevistador: André S. Avrichir). São Paulo, 2015e.

SILVA, Gabriela da. Entrevista Gabriela da Silva (Entrevistador: André S. Avrichir). São Paulo, 2015f.

SILVA, Helena da. Entrevista Helena da Silva (Entrevistador: André S. Avrichir). 2015g.

SOUSA, André A. et al. Pioneirismo em parcerias público-privadas: o modelo alternativo de atendimento ao cidadão no governo de Minas Gerais. In: CONGRESSO CONSAD DE GESTÃO PÚBLICA, 5., 2012, Brasília. Anais... Brasília: Consad, 2012.

THAMER, Rogério; LAZZARINI, Sérgio G. Projetos de parceria público-privada: fatores que influenciam o avanço dessas iniciativas. Rev. Adm. Pública, Rio de Janeiro, v. 49, n. 4, p. 819-846, July/Aug. 2015.

WILLIAMSON, Oliver. Franchise bidding for natural monopolies in general and with respect to CATV. The Bell Journal of Economics, v. 7, n. 1, p. 73-104, 1976.

WILliaMSON, Oliver. Public and private bureaucracies: a transaction cost economics perspectives. Journal of Law Economics and Organization, v. 15, n. 1, p. 306-342, 1999.

WILLIAMSON, Oliver. Outsourcing: transaction cost economics and supply chain management. Journal of Supply Chain Management, p. 5-16, Apr. 2008.

WILLIAMSON, Oliver. The economic institutions of capitalism: firms, markets, relational contracting. New York: Free Press, 1985.

WISEMAN, Jane. Can 311 Call centers improve service deliver? Lessons from New York and Chicago. In: INTERNATIONAL DEVELOPMENT BANK (Org). Innovations in public service delivery. Washington, DC: IDB, 2014. 
YIN, Robert K. Estudo de caso: planejamento e métodos. Porto Alegre: Sage, 2001.
YESCOMBE, E. R. Public-private partnerships: principles of policy and finance. London: Elsevier Inc., 2007.

\section{André Schifnagel Avrichir}

Master in Public Administration and Government from the School of Business Administration of São Paulo of the Fundação Getulio Vargas and Economist from the Universidade de São Paulo. E-mail: andre.avrichir@ gmail.com. 